\title{
Evaluation of Factorial Validity and Reliability of a Food Behavior Checklist for Low-Income Filipinos
}

\author{
Asuka Suzuki, RDN ${ }^{1}$; So Yung Choi, $\mathrm{MS}^{2}$; Eunjung Lim, PhD ${ }^{2}$; Socorro Tauyan, $\mathrm{MPH}^{1}$; \\ Jinan C. Banna, PhD, RDN ${ }^{1}$
}

\begin{abstract}
Objective: To examine factorial validity, test-retest reliability, and internal consistency of a Tagaloglanguage food behavior checklist (FBC) for a low-income Filipino population.

Methods: Participants $(n=160)$ completed the FBC on 2 occasions 3 weeks apart. Factor structure was examined using principal component analysis. For internal consistency, Cronbach $\alpha$ was calculated. For test-retest reliability, Spearman correlation or intraclass correlation coefficient (ICC) was calculated between scores at the 2 points.

Results: All but 1 item loaded on 6 factors: fruit and vegetable quantity, fruit and vegetable variety, fast food, sweetened beverage, healthy fat, and diet quality. Cronbach $\alpha$ was .75 for the total scale (range, .39-.76 for subscales). Spearman correlation was 0.78 (ICC, 0.79) for the total scale (range, 0.66-0.80 [ICC, 0.68-0.80] for subscales).

Conclusions and Implications: The FBC demonstrated adequate factorial validity, test-retest reliability, and internal consistency. With additional testing, the FBC may be used to evaluate the US Department of Agriculture's nutrition education programs for Tagalog speakers.

Key Words: survey, validity, reliability, Filipino, Tagalog, food behavior (J Nutr Educ Behav. 2017;49:593598.)

Accepted April 26, 2017.
\end{abstract}

\section{INTRODUCTION}

The number of Asian American people in the US has been increasing, including Filipino individuals. ${ }^{1,2}$ Filipino people are the third largest ethnic group among Asian American populations and grew from 3.4 million in 2011 to 3.9 million in 2015. ${ }^{2,3}$ Data spanning 2009 to 2013 show that 1.6 million people speak Tagalog, the official national language of the Philippines. ${ }^{4}$ Of the total population of Tagalog speakers in the US, 32.8\% speak English at a level classified as less than very well, which indicates that these individuals may be helped with translation services, education, or assistance in accessing government services. ${ }^{4}$

A systematic review of overweight and obesity among Asian American populations between 1988 and 2009 showed that Filipino individuals had the highest body mass index, at $26.8 \mathrm{~kg} / \mathrm{m}^{2}{ }^{5}$ A second literature review revealed that Filipino American people were at high risk for cardiovascular disease, hypertension, type 2 diabetes, and metabolic syndrome even at lower body mass index levels. ${ }^{6}$ Recent research also indicated that Filipino people were the only Asian American

\footnotetext{
${ }^{1}$ Department of Human Nutrition, Food, and Animal Sciences, College of Tropical Agriculture and Human Resources, University of Hawaii at Manoa, Honolulu, HI

${ }^{2}$ Biostatistics Core Facility, Department of Complementary \& Integrative Medicine, John A. Burns School of Medicine, University of Hawaii at Manoa, Honolulu, HI

Conflict of Interest Disclosure: The authors' conflict of interest disclosures can be found online with this article on www.jneb.org.

Address for correspondence: Jinan C. Banna, PhD, RDN, Department of Human Nutrition, Food, and Animal Sciences, College of Tropical Agriculture and Human Resources, University of Hawaii at Manoa, Agricultural Sciences 216, 1955 East-West Rd, Honolulu, HI 96822; Phone: (808) 956-7857; Fax: (808) 956-4024; E-mail: jcbanna@, hawaii.edu

(C2017 Society for Nutrition Education and Behavior. Published by Elsevier, Inc. All rights reserved.

http://dx.doi.org/10.1016/j.jneb.2017.04.019
}

group that had higher rates of hypertension than white American people. ${ }^{7}$ Similarly, another study showed that Filipino American people in northern California had the highest hypertension prevalence compared with other minority groups. ${ }^{8}$ In addition, Filipino American individuals had the second highest odds of prevelant type 2 diabetes, followed by other Asian, Chinese, and white people. ${ }^{9}$

Encouraging healthy dietary habits and healthy weight is the important for preventing diet-related chronic disease. Research demonstrated that community programs run by the US Department of Agriculture (USDA), such as the Supplemental Nutrition Assistance Program-Education (SNAP-Ed) and the Expanded Food and Nutrition Education Program (EFNEP), had an effect on positive diet-related behavior changes. ${ }^{10}$ In addition, a communitybased study in low-income Filipino people with cardiovascular disease risk factors in Hawai'i reported that providing a curriculum using appropriate cultural and bilingual tools improved outcomes. ${ }^{11}$ Evaluation of such programs using tools appropriate for the target group is an essential step in determining program effectiveness 
Table 1. Demographic Characteristics of Low-Income Filipino People in O'ahu, Hawai'i $(n=160)$

\begin{tabular}{|c|c|}
\hline Variable & $\begin{array}{c}\text { Mean } \pm \text { SD } \\
\text { (range) or } n(\%)\end{array}$ \\
\hline Age, y (mean \pm SD [range]) & $56.9 \pm 19.8(18-90)$ \\
\hline $\begin{array}{l}\text { Children in house, } \mathrm{n} \\
0 \\
1 \\
2 \\
3 \\
\geq 4 \\
\text { No response }\end{array}$ & $\begin{array}{c}66(41) \\
25(16) \\
25(16) \\
21(13) \\
20(12) \\
3(2)\end{array}$ \\
\hline $\begin{array}{l}\text { Sex } \\
\quad \text { Male } \\
\text { Female }\end{array}$ & $\begin{array}{r}48(30) \\
112(70)\end{array}$ \\
\hline Education, y (mean \pm SD [range]) & $11.2 \pm 3.5(1-18)$ \\
\hline $\begin{array}{l}\text { Highest level of education } \\
\text { Did not complete high school } \\
\text { Completed high school } \\
\text { Completed post-high school training or some college } \\
\text { Graduated from 4-y college or university } \\
\text { Attended and/or completed graduate school } \\
\text { Other }\end{array}$ & $\begin{array}{c}31(19) \\
35(22) \\
33(21) \\
46(29) \\
5(3) \\
10(6)\end{array}$ \\
\hline $\begin{array}{l}\text { Employment } \\
\text { Employed for wages } \\
\text { Self-employed } \\
\text { Out of work and looking for work } \\
\text { Out of work but not currently looking for work } \\
\text { Retired } \\
\text { Other }\end{array}$ & $\begin{array}{c}68(43) \\
9(6) \\
19(12) \\
3(2) \\
52(33) \\
9(6)\end{array}$ \\
\hline $\begin{array}{l}\text { Birthplace } \\
\text { US } \\
\text { Philippines }\end{array}$ & $\begin{array}{c}4(3) \\
156(98)\end{array}$ \\
\hline
\end{tabular}

Note: Percentages may not add up to 100 owing to rounding.

in diverse populations. ${ }^{12}$ However, valid and reliable tools in Tagalog are lacking to evaluate such programs in low-income Filipino groups.

A food behavior checklist (FBC) is a tool that may be used to evaluate the impact of nutrition education on dietary intake in low-income populations. This tool is a brief questionnaire containing items on intake of fruits and vegetables, dairy, sweetened beverages, and fried food, as well as food security and overall diet quality. $^{13,14}$ A previous study examined the face validity of a Tagalog-language version of this tool in the Filipino population in the US. Face validity was deemed adequate based on: (1) approval of text and photographs by members of the target population via cognitive interviews; (2) approval of text and photographs by a panel of professionals using a team-based approach; and (3) achievement of a readability score appropriate for a low-literacy audience. ${ }^{15}$

The objective of this study was to examine the factorial validity, testretest reliability, and internal consistency of the Tagalog-language FBC for low-income Filipino people.

\section{METHODS}

The Institutional Review Board of the University of Hawai'i at Manoa provided approval for this study.

\section{Sample}

A researcher fluent in Tagalog recruited Filipino subjects in O'ahu, Hawai'i who spoke Tagalog as a first language $(\mathrm{n}=160)$, were aged $>18$ years, and met income eligibility for SNAP-Ed ${ }^{16}$ from the Filipino Center, churches, low-income housing complexes, and other community sites.

\section{Measures}

Participants provided sociodemographic information and completed the 22-item Tagalog-language FBC on 2 occasions 3 weeks apart. Sociodemographic information included age, sex, number of children in the house, education, employment status, and birth place.

\section{Data Analysis}

The researchers performed analyses using SAS 9.4 for Windows (SAS Institute, Cary NC). All responses on the FBC were recoded on a 4-point scale ranging from 1 to 4 , with higher scores indicating more desirable behavior.

For item analysis, mean responses and SDs were calculated for each item to determine potential of items to reflect behavior change as the result of an intervention. Dichotomous (yes/ no) items with a mean of $>2.6$ and all other items with a mean of $>3$ were considered to have little potential to reflect behavior change. ${ }^{17}$

For factor validity, the researchers first segregated items by predetermined categories: fruits and vegetables, milk and dairy, food security, and remaining items. Factor validity was examined using principal component analysis (PCA) with varimax rotation for each category with at least 2 items at the first point. To assess the numbers of factors, Kaiser criterion (eigenvalues $>1.0$ ), scree plot, and parallel analysis were initially used. Any item with a factor loading $>0.50$ was considered to load on the given factor, ${ }^{18}$ in conjunction with review of the content of the individual items. Based on the results of the Kaiser criterion and parallel analysis, the researchers requested factor solutions with different numbers of factors and selected the solution that generated the most comprehensible factor structure. ${ }^{19}$

To assess internal consistency, Cronbach $\alpha$ was calculated for each subscale and total scale at the first time point. The researchers considered $\alpha>.70$ to be acceptable. ${ }^{20}$

To assess test-retest reliability, Spearman correlation with $95 \%$ confidence 
Table 2. Factor Validity and Item Analysis for 22 Items on Tagalog-Language Food Behavior Checklist for Low-Income Filipino People in O'ahu, Hawai'i $(\mathrm{n}=160)$

\begin{tabular}{|c|c|c|c|}
\hline Food Behavior Item & $\begin{array}{l}\text { Factor } \\
\text { Loading }\end{array}$ & $\begin{array}{c}\text { Mean } \\
\text { Response }\end{array}$ & SD \\
\hline $\begin{array}{l}\text { Fruit and vegetable quantity subscale } \\
\text { 1. Cups of fruit each day } \\
\text { 2. Servings of fruit each day } \\
\text { 3. Cups of vegetable each day } \\
\text { 4. Servings of vegetable each day }\end{array}$ & $\begin{array}{c}\text { Factor } 1 \\
0.79 \\
0.76 \\
0.53 \\
0.61\end{array}$ & $\begin{array}{l}2.40 \\
3.54 \\
2.60 \\
3.68\end{array}$ & $\begin{array}{l}0.73 \\
0.55 \\
0.74 \\
0.53\end{array}$ \\
\hline $\begin{array}{l}\text { Fruit and vegetable variety subscale } \\
\text { 5. Fruits or vegetables as snacks } \\
6 .>1 \text { kind of fruit each day } \\
\text { 7. }>1 \text { kind of vegetable each day } \\
8 . \geq 2 \text { vegetables at main meal } \\
\text { Does not load on any factor at }>0.50 \text { : } \\
\text { 9. Citrus fruits or citrus juice during } \\
\text { past week }\end{array}$ & $\begin{array}{c}\text { Factor } 2 \\
0.52 \\
0.60 \\
0.90 \\
0.89\end{array}$ & $\begin{array}{l}2.94 \\
2.78 \\
3.31 \\
3.13\end{array}$ & $\begin{array}{l}0.89 \\
0.92 \\
0.79 \\
0.90\end{array}$ \\
\hline $\begin{array}{l}\text { Milk/dairy subscale } \\
\text { 10. Drink milk } \\
\text { 11. Drank milk or used milk on cereal in } \\
\text { past week }\end{array}$ & $\begin{array}{l}N / A \\
N / A\end{array}$ & $\begin{array}{l}2.56 \\
2.74\end{array}$ & $\begin{array}{l}1.06 \\
1.48\end{array}$ \\
\hline $\begin{array}{l}\text { Food security item } \\
\text { 12. Run out of food before end of month }\end{array}$ & $\mathrm{N} / \mathrm{A}$ & 3.44 & 0.72 \\
\hline $\begin{array}{l}\text { Fast food subscale } \\
\text { 13. Fried snacks yesterday } \\
\text { 14. Fried food yesterday } \\
\text { 15. Fast food yesterday } \\
\text { 16. Red meat or pork yesterday }\end{array}$ & $\begin{array}{c}\text { Factor } 3 \\
0.61 \\
0.62 \\
0.74 \\
0.57\end{array}$ & $\begin{array}{l}2.48 \\
1.94 \\
3.14 \\
1.88\end{array}$ & $\begin{array}{l}1.50 \\
1.39 \\
1.36 \\
1.37\end{array}$ \\
\hline $\begin{array}{l}\text { Sweetened beverage subscale } \\
\text { 17. Drink fruit drinks, sport drinks, or punch } \\
\text { 18. Drink regular soda }\end{array}$ & $\begin{array}{c}\text { Factor } 4 \\
0.86 \\
0.81\end{array}$ & $\begin{array}{l}3.18 \\
3.19\end{array}$ & $\begin{array}{l}0.79 \\
0.82\end{array}$ \\
\hline $\begin{array}{l}\text { Healthy fat subscale } \\
\text { 19. Fish during past week } \\
\text { 20. Take skin off chicken }\end{array}$ & $\begin{array}{c}\text { Factor } 5 \\
0.77 \\
0.71\end{array}$ & $\begin{array}{l}3.81 \\
2.78\end{array}$ & $\begin{array}{l}0.73 \\
1.48\end{array}$ \\
\hline $\begin{array}{l}\text { Diet quality subscale } \\
\text { 21. Use label when food shopping } \\
\text { 22. Rate eating habits }\end{array}$ & $\begin{array}{c}\text { Factor } 6 \\
0.85 \\
0.62\end{array}$ & $\begin{array}{l}2.67 \\
2.70\end{array}$ & $\begin{array}{l}1.50 \\
0.59\end{array}$ \\
\hline
\end{tabular}

$\mathrm{N} / \mathrm{A}$ indicates Not applicable.

Notes: Factor structures were not examined for factors with $\leq 2$ items. Analyses were performed using responses to the food behavior checklist at the first time point.

interval or intraclass correlation coefficient (ICC) was calculated between scores at the 2 time points for each item, each subscale, and the total scale. These are the 2 most commonly used methods to assess test-retest reliability. ${ }^{21,22}$ In addition, kappa $(\kappa)$ coefficients were computed, either unweighted or weighted, depending on the number of categories in the responses. The following standards for strength of agreement for $\kappa$ coefficients were used: 0 or lower $=$ poor; $0.01-0.20=$ slight, $0.21-0.40=$ fair, $0.41-0.60=$ moderate; $0.61-0.80=$ substantial; and $0.80-1.0=$ almost perfect. ${ }^{23}$ Items referring to yesterday or the past week were excluded from testretest reliability analysis owing to the reference to a specific period of time.

\section{RESULTS}

Average age of participants was 57 years (SD, 20 years); $70 \%$ of participants were female. Most participants (98\%) were born in the Philippines and $41 \%$ had completed high school or less as the highest level of education. Table 1 lists demographic characteristics of participants.
Results of the PCA with varimax rotation are displayed in Table 2, as well as mean and SD of each item. Six factors were identified: (1) fruit and vegetable quantity, (2) fruit and vegetable variety, (3) fast food, (4) sweetened beverage, (5) healthy fat, and (6) diet quality. Eighteen items loaded on a factor except for the item on citrus fruit and juice consumption. The predetermined milk and dairy subscale and food security item, which were not included in the PCA, are included in Table 2.

Table 3 presents internal consistency and test-retest reliability. Cronbach $\alpha$ 's for internal consistency of subscales ranged from .39 (diet quality subscale) to .76 (fruit and vegetable variety subscale) and $\alpha$ for the total scale was .75. Spearman correlations for test-retest reliability for individual items ranged from 0.48 to 0.78 (ICC, $0.50-0.78$ ) whereas correlations for each subscale ranged from 0.66 to 0.80 (ICC, 0.68-0.80). The correlation for test-retest reliability for the total scale was 0.78 (ICC, 0.79). All items and subscales and the total scale met the criterion for acceptability $(P<.05)$ using Spearman correlation coefficients. The $\kappa$ coefficient values ranged from 0.48 to 0.74 , indicating moderate to substantial strength of agreement between the test and retest.

\section{DISCUSSION}

The current study indicated that the Tagalog-language FBC had adequate factorial validity, test-retest reliability, and internal consistency.

The PCA revealed that all but 1 item loaded on identified factors. The citrus item did not load on any factor and had a high mean response value. This item did not perform well when a Spanish-language version of the questionnaire was tested in lowincome Spanish speakers and was selected for deletion. ${ }^{17}$ If it is found not to correlate with nutrient intake in future studies, this item may be modified and tested further, or may be considered for deletion.

With regard to test-retest reliability, all items and subscales and the total scale were found to be acceptable. Regarding internal consistency, Cronbach $\alpha$ of $>0.70$ was considered acceptable. ${ }^{20}$ Based on this criterion, internal consistency was low 
Table 3. Internal Consistency and Test-Retest Reliability of Tagalog-Language Food Behavior Checklist Completed by LowIncome Filipino People in O'ahu, Hawai'i $(n=160)$

Test-Retest Reliability

\begin{tabular}{|c|c|c|c|c|c|}
\hline Food Behavior Item & $\alpha$ & $\rho^{\mathrm{a}}$ & Interval & Coefficient & Interval) \\
\hline $\begin{array}{l}\text { Factor } 1 \text { : fruit and vegetable quantity subscale } \\
\text { 1. Cups of fruit each day } \\
\text { 2. Servings of fruit each day } \\
\text { 3. Cups of vegetable each day } \\
\text { 4. Servings of vegetable each day }\end{array}$ & .70 & $\begin{array}{l}0.67 \\
0.60 \\
0.57 \\
0.59 \\
0.58\end{array}$ & $\begin{array}{l}0.58-0.75 \\
0.49-0.69 \\
0.45-0.67 \\
0.48-0.68 \\
0.46-0.67\end{array}$ & $\begin{array}{l}0.71 \\
0.62 \\
0.55 \\
0.56 \\
0.63\end{array}$ & $\begin{array}{l}0.54(0.46-0.63) \\
0.48(0.38-0.58) \\
0.51(0.39-0.63) \\
0.46(0.36-0.56) \\
0.57(0.44-0.71)\end{array}$ \\
\hline $\begin{array}{l}\text { Factor } 2 \text { : fruit and vegetable variety subscale } \\
\text { 5. Fruit or vegetables as snacks } \\
\text { 6. }>1 \text { kind of fruit each day } \\
\text { 7. }>1 \text { kind of vegetable each day } \\
\text { 8. } \geq 2 \text { vegetables at main meal } \\
\text { Does not load on any factor at }>0.50 \text { : } \\
\text { 9. Citrus fruits or citrus juice during past week }\end{array}$ & .76 & $\begin{array}{l}0.69 \\
0.48 \\
0.61 \\
0.64 \\
0.64\end{array}$ & $\begin{array}{l}0.60-0.76 \\
0.36-0.59 \\
0.50-0.70 \\
0.54-0.72 \\
0.53-0.72\end{array}$ & $\begin{array}{l}0.71 \\
0.50 \\
0.59 \\
0.63 \\
0.65\end{array}$ & $\begin{array}{l}0.59(0.51-0.68) \\
0.49(0.37-0.61) \\
0.52(0.41-0.62) \\
0.58(0.47-0.69) \\
0.57(0.47-0.68)\end{array}$ \\
\hline $\begin{array}{l}\text { Milk/dairy subscale } \\
\text { 10. Drink milk } \\
\text { 11. Drank milk or used milk on cereal in past week }\end{array}$ & .45 & $\begin{array}{l}0.72 \\
\text { N/A }\end{array}$ & $\begin{array}{c}0.64-0.79 \\
\text { N/A }\end{array}$ & $\begin{array}{l}0.72 \\
\text { N/A }\end{array}$ & $\begin{array}{c}0.66(0.56-0.75) \\
\text { N/A }\end{array}$ \\
\hline $\begin{array}{l}\text { Food security item } \\
\text { 12. Run out of food before end of month }\end{array}$ & $\mathrm{N} / \mathrm{A}$ & 0.78 & $0.71-0.84$ & 0.74 & $0.72(0.62-0.82)$ \\
\hline $\begin{array}{l}\text { Factor 3: fast food subscale } \\
\text { 13. Fried snacks yesterday } \\
\text { 14. Fried food yesterday } \\
\text { 15. Fast food yesterday } \\
\text { 16. Red meat or pork yesterday }\end{array}$ & .57 & $\begin{array}{l}\text { N/A } \\
\text { N/A } \\
\text { N/A } \\
\text { N/A }\end{array}$ & $\begin{array}{l}\text { N/A } \\
\text { N/A } \\
\text { N/A } \\
\text { N/A }\end{array}$ & $\begin{array}{l}\text { N/A } \\
\text { N/A } \\
\text { N/A } \\
\text { N/A }\end{array}$ & $\begin{array}{l}\text { N/A } \\
\text { N/A } \\
\text { N/A } \\
\text { N/A }\end{array}$ \\
\hline $\begin{array}{l}\text { Factor 4: sweetened beverage subscale } \\
\text { 17. Drink fruit drinks, sport drinks, or punch } \\
\text { 18. Drink regular soda }\end{array}$ & .68 & $\begin{array}{l}0.80 \\
0.71 \\
0.78\end{array}$ & $\begin{array}{l}0.73-0.85 \\
0.63-0.78 \\
0.71-0.83\end{array}$ & $\begin{array}{l}0.80 \\
0.74 \\
0.78\end{array}$ & $\begin{array}{l}0.70(0.62-0.78) \\
0.68(0.59-0.78) \\
0.74(0.65-0.83)\end{array}$ \\
\hline $\begin{array}{l}\text { Factor 5: healthy fat subscale } \\
\text { 19. Fish during past week } \\
\text { 20. Take skin off chicken }\end{array}$ & .41 & $\begin{array}{l}0.69 \\
\mathrm{~N} / \mathrm{A} \\
0.69\end{array}$ & $\begin{array}{l}0.60-0.76 \\
\mathrm{~N} / \mathrm{A} \\
0.60-0.76\end{array}$ & $\begin{array}{l}0.69 \\
\mathrm{~N} / \mathrm{A} \\
0.69\end{array}$ & $\begin{array}{l}0.69(0.57-0.80)^{\mathrm{b}} \\
\mathrm{N} / \mathrm{A} \\
0.69(0.57-0.80)^{\mathrm{b}}\end{array}$ \\
\hline $\begin{array}{l}\text { Factor 6: diet quality subscale } \\
\text { 21. Use label when food shopping } \\
\text { 22. Rate eating habits }\end{array}$ & .39 & $\begin{array}{l}0.66 \\
0.66 \\
0.59\end{array}$ & $\begin{array}{l}0.56-0.74 \\
0.57-0.74 \\
0.48-0.68\end{array}$ & $\begin{array}{l}0.68 \\
0.65 \\
0.57\end{array}$ & $\begin{array}{l}0.61(0.52-0.71) \\
0.65(0.53-0.77)^{b} \\
0.53(0.42-0.63)\end{array}$ \\
\hline Total scale & .75 & 0.78 & $0.71-0.83$ & 0.79 & \\
\hline
\end{tabular}

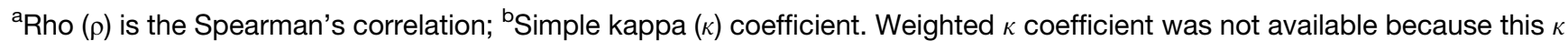
statistic was based on the $2 \times 2$ table.

for the fast-food subscale containing 4 items. Internal consistency was also low for other subscales containing only 2 items, namely diet quality, healthy fat, sweetened beverage, and milk and dairy. However, this was expected given the low number of items these subscales contained, because the coefficient increases with the number of items in the scale. ${ }^{24}$ The ideal number of items for a scale to achieve solid internal consistency reliability is $\geq 5^{18}$; there were fewer items in the scales in the current study because this was a brief tool for use in the community. Furthermore, the low values indicate that the items in the subscales may have reflected different behaviors within each construct, allowing for evaluation of important dietary practices. Given this, all items in these subscales may be considered for the final tool. Similar results were found in a previous study evaluating a Spanish-language FBC, in which the correlation coefficient for the 2 milk and dairy items was also low. ${ }^{17}$ This low correlation may have indicated that the 2 items reflected different behaviors within the dairy domain construct. None of the subscales had Cronbach $\alpha \geq .90$, which suggests redundancies of items. ${ }^{20}$
The item analysis showed that 12 items (eg, eat more than 1 kind of vegetable each day, eat fast food yesterday) of 22 had a mean response exceeding the cutoff with regard to the potential to reflect behavior change. If participants were already performing the behavior in question, there would be little opportunity for improvement through nutrition education. In further testing the questionnaire, it may be possible to consider featuring other relevant behaviors. For example, previous studies pointed to the possibility of higher consumption of high-caloric foods 
reserved for celebration in the home country among Filipino people in the US. ${ }^{25,26}$ For example, because the item that focused on the consumption of fast food had a high mean response, it may be more appropriate to focus on the consumption of ceremonial foods such as lechón (roasted pig) as a source of fat. ${ }^{27}$

Additional testing of the tool is needed to assess convergent and criterion validity. Previous studies evaluating the validity of the English and Spanish versions of the FBC involved collection of 24-hour dietary recalls to evaluate convergent validity, and serum carotenoids as a marker of fruit and vegetable intake to assess criterion validity. ${ }^{13,17}$ Similar procedures may be followed for further testing of the Tagalog FBC to compare nutrient intake with questionnaire respon ses. In addition, confirmatory factor analysis may be conducted to confirm the factor structure of the tool in the Filipino population. Based on additional data to be collected, it will be possible to determine which items should be eliminated from the tool. After testing is completed, the FBC may be used to evaluate the USDA's nutrition education programs.

Findings of the current study may not be generalized beyond the population of low-income Filipino individuals participating in this study, because a convenience sample was used. In addition, the timing of when the questionnaire was administered was not considered in this study, and responses may have been affected by factors such as when food aid was received or when food aid ran out. Furthermore, the questionnaire presented items only in the Tagalog language and did not include other regional languages such as Ilocano, which is commonly spoken among Filipino people in Hawai'i. However, because Tagalog is the official national language of the Philippines, the researchers anticipate that the questionnaire may be widely useful in the Filipino population in the US.

\section{IMPLICATIONS FOR RESEARCH AND PRACTICE}

The Tagalog-language FBC is a brief tool with 8 subscales that is reliable for use in the low-income Filipino population. After further testing, this tool may be used to evaluate the effects of the USDA's nutrition education programs, as well as an assessment tool to set program goals. Because brief evaluation tools in the language of the target population are needed to evaluate nutrition education programs in a timeefficient manner, this questionnaire may prove useful for improving and planning programs. A future study is planned to examine the convergent and criterion validity of the tool.

\section{ACKNOWLEDGMENTS}

This work had financial support from National Institute of General Medical Sciences Grant 5U54 GM104944 and National Institute on Minority Health and Health Disparities Grant U54 MD007584. The authors also thank the participants in the study, as well as Ashley Yamanaka, Adrienne McDonald, Lucia Amore, and Kristina Salazar for their assistance with data entry.

\section{REFERENCES}

1. US Census Bureau. The Asian population: 2010 Census briefs. http://www. census.gov/prod/cen2010/briefs/c2010br11.pdf. Accessed January 13, 2017.

2. US Census Bureau. 2015 American Community Survey 1-year estimates. https://factfinder.census.gov/faces/table services/jsf/pages/productview.xhtml? pid=ACS_15_1YR_B02018\&prodType $=$ table. Accessed January 13, 2017.

3. US Census Bureau. 2011 American Community Survey 1-year estimates. https://factfinder.census.gov/faces/table services/jsf/pages/productview.xhtml? pid=ACS_11_1YR_B02018\&prodType =table. Accessed January 13, 2017.

4. US Census Bureau. Detailed languages spoken at home and ability to speak English for the population 5 years and over: 2009-2013, American Community Survey. http://www.census.gov/ data/tables/2013/demo/2009-2013-langtables.html. Accessed January 13, 2017.

5. Staimez LR, Weber MB, Narayan KM, Oza-Frank R. A systematic review of overweight, obesity, and type 2 diabetes among Asian American subgroups. Curr Diabetes Rev. 2013;9: 312-331.
6. Abesamis CJ, Fruh S, Hall H, Lemley T, Zlomke KR. Cardiovascular health of Filipinos in the United States: a review of the literature. I Transcult Nurs. 2016;27:518-528.

7. Ye J, Rust G, Baltrus P, Daniels E. Cardiovascular risk factors among Asian Americans: results from a National Health Survey. Ann Epidemiol. 2009; 19:718-723.

8. Zhao B, Jose PO, Pu J, et al. Racial/ ethnic differences in hypertension prevalence, treatment, and control for outpatients in northern California 2010-2012. Am J Hypertens. 2015;28:631-639.

9. Lee JW, Brancati FL, Yeh HC. Trends in the prevalence of type 2 diabetes in Asians versus whites: results from the United States National Health Interview Survey, 1997-2008. Diabetes Care. 2011;34:353-357.

10. Hersey J CS, Blitstein J, Williams P. SNAP-Ed can improve nutrition of low-income Americans across life span. http://www.rti.org/sites/default/ files/resources/rr-0023-1406-cates.pdf. Accessed January 13, 2017.

11. Fernandes R, Braun KL, Spinner JR, et al. Healthy Heart, Healthy Family: a NHLBI/HRSA collaborative employing community health workers to improve heart health. I Health Care Poor Underserved. 2012;23:988-999.

12. Townsend MS. Evaluating food stamp nutrition education: process for development and validation of evaluation measures. J Nutr Educ Behav. 2006;38: $18-24$.

13. Murphy SP, Kaiser LL, Townsend MS, Allen LH. Evaluation of validity of items for a food behavior checklist. J Am Diet Assoc. 2001;101:751-761.

14. Townsend MS, Kaiser LL, Allen LH, Joy AB, Murphy SP. Selecting items for a food behavior checklist for a limited-resource audience. J Nutr Educ Behav. 2003;35:69-77.

15. Banna JC, Buchthal OV, Tauyan S. Assessing face validity of a food behavior checklist for limited-resource Filipinos. Hawai'i J Med Public Health. 2015;74: 334-340.

16. US Department of Agriculture Food and Nutrition Service. Supplemental Nutrition Assistance Program (SNAP) eligibility. https://www.fns.usda.gov/ snap/eligibility. Accessed April 1, 2017.

17. Banna JC, Townsend MS. Assessing factorial and convergent validity and reliability of a food behaviour checklist for Spanish-speaking participants in US Department of Agriculture nutrition 
education programmes. Public Health Nutr. 2011;14:1165-1176.

18. Costello A, Osborne J. Best practices in explanatory factor analysis: four recommendations for getting the most from your analysis. Practical Assessment, Research \& Evaluation. 2005;10: $1-8$.

19. Garson GD. Factor Analysis. Asheboro, NC: Statistical Associates Publishers; 2013.

20. George D, Mallery P. SPSS for Windows step by step: A simple guide and reference 11.0 update. 4th ed. Boston, MA: Allyn \& Bacon; 2003.
21. Maruti SS, Feskanich D, Colditz GA, et al. Adult recall of adolescent diet: reproducibility and comparison with maternal reporting. Am J Epidemiol. 2005;161:89-97.

22. Fernandez-Ballart JD, Pinol JL, Zazpe I, et al. Relative validity of a semiquantitative food-frequency questionnaire in an elderly Mediterranean population of Spain. Br J Nutr. 2010;103:1808-1816.

23. Landis JR, Koch GG. The measurement of observer agreement for categorical data. Biometrics. 1977;33:159-174.

24. Streiner DL. Starting at the beginning: an introduction to coefficient alpha and internal consistency. J Pers Assess. 2003;80:99-103.

25. Vargas P, Jurado LF. Dietary acculturation among Filipino Americans. Int J Environ Res Public Health. 2016;13:16.

26. Azar KM, Chen E, Holland AT, Palaniappan LP. Festival foods in the immigrant diet. J Immigr Minor Health. 2013;15:953-960.

27. Johnson-Kozlow M, Matt GE, Rock CL, de la Rosa R, Conway TL, Romero RA. Assessment of dietary intakes of Filipino-Americans: implications for food frequency questionnaire design. J Nutr Educ Behav. 2011;43:505-510.

\section{Position Announcement: Associate Editor for JNEB}

The Journal of Nutrition Education and Behavior is seeking applicants for Associate Editor. For full details, see our description online:

http://www.jneb.org/content/associate-editor-applicants 


\section{CONFLICT OF INTEREST}

The authors have not stated any conflicts of interest. 